\title{
Assessment of Factors Influencing Trace Element Content of the Basidiomycetes in the European Part of Russia
}

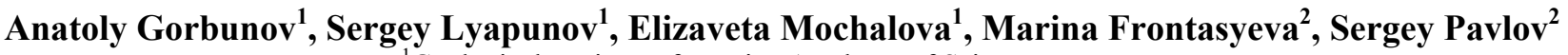 \\ ${ }^{1}$ Geological Institute of Russian Academy of Sciences, Moscow \\ ${ }^{2}$ Joint Institute for Nuclear Research, Dubna, Russia \\ Email:marina@nf.jinr.ru
}

Received October 15, 2013; revised November 15, 2013; accepted November 22, 2013

Copyright (C) 2013 Anatoly Gorbunov et al. This is an open access article distributed under the Creative Commons Attribution License, which permits unrestricted use, distribution, and reproduction in any medium, provided the original work is properly cited.

\begin{abstract}
The article presents concentrations of 29 trace elements in different groups of basidiomycetes: saprotrophic, parasitic and symbiotic. The potential of using the concentration factor $\left(\mathrm{K}_{\mathrm{c}}\right)$ is shown for the assessment of trace element accumulation by the fungi. The variations of trace element concentrations in different ecological and geochemical environment are presented. The data obtained in this research made it possible to mark out the group of trace elements that are mainly accumulated by fungi. This information helped to assess the correlation between the trace element concentrations in the mycothalluses of fungi and their mobile forms in the soil. The expected patterns of the trace element accumulation in fungi are described.
\end{abstract}

Keywords: Basidiomycetes; Mycelium; Microelements; Storage; Mobile Forms

\section{Introduction}

Fungi are a large group of eukaryotic heterotrophic organisms classified as a separate kingdom (Mycota or Fungi). They keep an intermediate position between the animal and the vegetable kingdoms. On the one hand, fungi lack chlorophyll and therefore need preformed organic compounds for their nutrition. The result of their metabolism is urea. Their cell walls contain chitin, and the storage compound is the glycogen instead of the starch, which is closer to the animals. On the other hand, their way of nutrition (by absorbing the solutions of the organic substances) and their unlimited growth are closer to the plants. The metabolism of the mushrooms leads to the transformation of the complex organic substances into less complex compounds and into the mineral ones at the end. Simple compounds are transferred directly through the cell membranes; the more complex substances are decomposed to monomers by extracellular enzymes. There are data about the Zn-fixation by the organic substances in the metabolism of fungi, the inclusion of $\mathrm{Co}$ into the $\mathrm{B}_{12}$-molecule in the synthesis of this vitamin, and the selective accumulation of toxic elements (such as selenium, lead, cadmium, mercury) by some types of fungi [1-3]. In consideration of the numerous literature data, the high concentrations of various trace elements in fungi are not in question [4-7]. For this reason, mushrooms are considered to be the accumulators, and the selective ones, of the trace elements and, in particular, of heavy and toxic metals. However, the combination of the selective accumulation of any trace elements with the osmotrophic (diffuse) way of nutrition of the mushrooms is doubtful. Is the accumulation process actually internal or can the high concentration of the minerals be explained by external reasons? The purpose of this work is to assess the features of the trace element accumulation by basidiomycetes.

\section{The Methodology of Sampling and Analysis}

Since we were interested only in edible mushrooms we analyzed the trace element composition of the basidiomycetes (Basidiomycota). This group includes the vast majority of fungi used as food, as well as many parasites of cultivated and wild plants. The group of basidiomycetes numbers more than 30,000 species. According to the way of nutrition of the higher fungi they can be saprotrophic, parasitic and symbiotic organisms.

The saprotrophic fungi include most of the pileate and mold fungi, as well as the yeast. Typical representatives of the saprotrophic fungi are russule, woolly milk cap, 
saffron milk cap and champignon.

Higher plants are most often hosts of the parasitic fungi (hemibiotrophs). During their growth fungi secrete enzymes that destroy the middle laminae between plant cells of the host plant, resulting in softening of the tissues. Some parasites gradually suck substances from the host, but do not lead to its death, while other secrete enzymes that decompose the cellulose of the cell walls, resulting in death of the host cell, following which the parasite feeds on the organic remains of the host. Typical representatives of the parasitic fungi are agaric honey, oyster mushrooms and bracket fungi.

Mycorrhiza forming fungi (symbiotrophs) enter into a mutually beneficial relationship with the plants in the form of mycorrhiza. Mycorrhiza is a mutually beneficial co-existence of the fungus and the roots of higher plants. Typical representatives of mycorrhizal fungi are basidiomycetes of the family Boletaceae: brown cap boletuses, aspen mushroom and cepes.

Sampling of mycothalluses was held in Moscow, Moscow Oblast, Kaluga Oblast, Tver Oblast, Nizhny Novgorod Oblast, Tula Oblast and Voronezh Oblast, the Kandalaksha Nature State Reserve and the Kostomuksha Nature Reserve. Samples of Boletus edulis, Leccinum scabrum, Leccinum aurantiacum, Suillus luteus, Russula vesca, Lactarius torminosus, Paxillus involutus, Cantharellus cibarius, Armillariella mellea, Agaricus campestris and Pleurotus ostreatus were selected. Also, the mycothalluses of cepes were sampled in the coastal areas of Iceland. Mushrooms grown in vitro like champignons (Agaricus bisporus) and oyster mushrooms (Pleurotus ostreatus) were selected as well. Mycothallus samples were collected in plastic Ziplock bags, cleared of external contamination, washed twice with distilled water, dried at the temperature $\mathrm{t}<60^{\circ} \mathrm{C}$ and ground to a size of $<1$ $\mathrm{mm}$. In the Tver Oblast the soil samples up to the depth of $50 \mathrm{~cm}$ were taken simultaneously. The soils were collected in plastic Ziplock bags as well, dried to air-dry state, sifted through a sieve with a hole diameter of $1 \mathrm{~mm}$ and reduced to powder.

The trace element analysis of the collected samples was carried out in the laboratory of the Geological Institute of the Russian Academy of Sciences (Moscow) using the instrumental neutron activation (INAA) [6-8] and atomic absorption (AA) methods. The INAA detected concentrations of $\mathrm{Na}, \mathrm{Mg}, \mathrm{Cl}, \mathrm{K}, \mathrm{Ca}, \mathrm{Sc}, \mathrm{Cr}, \mathrm{Co}, \mathrm{As}, \mathrm{Se}$, $\mathrm{Br}, \mathrm{Rb}, \mathrm{Mo}, \mathrm{Ag}, \mathrm{Sb}, \mathrm{I}, \mathrm{Cs}, \mathrm{La}, \mathrm{W}, \mathrm{Au}, \mathrm{Hg}$, Th and the AA detected concentrations of $\mathrm{Mn}, \mathrm{Fe}, \mathrm{Ni}, \mathrm{Cu}, \mathrm{Zn}, \mathrm{Cd}$, $\mathrm{Pb}$.

The quality and reliability control of the results was performed through the analysis of encrypted standard samples of IAEA-SOIL-7, IAEA-336 (Lichen), SRM 1572 (Citrus Leaves) and SRM 1575 (Pine Needles). The quality and reliability of analytical work were systemati- cally confirmed during analytical tests within the framework of international cooperation programs $[9,10]$.

\section{Results and Discussion}

Table 1 shows the average concentrations of trace elements in the mycothalluses of the symbiotrophs. It is important to stress that the only official criterion for normalizing the concentration of any element in mushrooms is the maximum permissible concentration (MPC) for foodstuff. It is determined by the sanitary inspection of the Russian Federation and is given relative to the "live" weight. Therefore, we can only compare the weight and concentrations with humidity. Moreover, men eat a natural product and not a sublimated one, so the element concentrations should be given relative to the humidity.

The data presented in the Table 1 show that the average concentrations of toxic elements $\mathrm{Se}, \mathrm{Cd}$ and $\mathrm{Hg}$ in the mushrooms Boletus edulis, of $\mathrm{Cd}$ and $\mathrm{Hg}$ in Leccinum scabrum and of $\mathrm{Cd}$ in Leccinum aurantiacum and Suillus luteus exceed the (MPC) [11] for the foodstuff. This refers to the arithmetical mean concentration. The maximal concentration of these toxic elements is almost $100 \%$ higher, according to the standard deviation. The concentration of $\mathrm{Cr}$, $\mathrm{As}$ and $\mathrm{Pb}$ does not exceed the established limits. Variability in concentrations of $\mathrm{Na}, \mathrm{Mg}$, $\mathrm{Cl}, \mathrm{K}$ and $\mathrm{Ca}$ is relatively small: $20 \%-50 \%$. Variability in concentrations of the other trace elements in mushrooms Boletus edulis, Leccinum scabrum and Leccinum aurantiacum is $50 \%-100 \%$, which means a significant irregularity of the trace element accumulation by these fungi.

Table 2 presents data on the concentration of trace elements in mycothalluses of saprotrophic fungi. The data presented in this table show that the average concentrations of $\mathrm{Se}, \mathrm{Cd}$ and $\mathrm{Hg}$ in Agaricus campestris exceed limit values (by 60 times for $\mathrm{Cd}$ and 12 times for $\mathrm{Hg}$ ). The high concentration of precious metals $\mathrm{Ag}$ and $\mathrm{Au}$ is noteworthy. The variation limits of the standard deviation are much wider than for symbiotrophs.

Table 3 shows the concentration of the trace elements in mycothalluses of parasitic fungi. It should be noted that the concentration of $\mathrm{Cd}$ exceeds the MPC in mycothalluses of these fungi 14- and 8-fold, and the concentration and the standard deviation of other trace elements in mycothalluses of Armillariella mellea and Pleurotus ostreatus are significantly lower than in saprotrophs and symbiotrophs.

The data presented in Tables 1, 2 and $\mathbf{3}$ show the natural concentrations of trace elements in mushrooms and limits of natural dispersion of these concentrations. The analysis of these data must be held with rather rough estimations as there is no objective mathematical criterion to assess the concentration level of trace elements in mushrooms. For the more accurate assessment of the 
Table 1. Trace element concentrations in symbiotrophic fungi, mcg/g (with humidity).

\begin{tabular}{|c|c|c|c|c|c|}
\hline Element & $\begin{array}{l}\text { Boletus edulis } \\
\quad \mathrm{n}=\mathbf{2 9}\end{array}$ & $\begin{array}{l}\text { Leccinum scabrum } \\
\qquad \mathrm{n}=\mathbf{2 0}\end{array}$ & $\begin{array}{l}\text { Leccinum } \\
\text { auraniacum } \\
\mathrm{n}=11\end{array}$ & $\begin{array}{l}\text { Suillus luteus } \\
\qquad \mathrm{n}=17\end{array}$ & MPC \\
\hline $\mathbf{N a}$ & $41 \pm 28$ & $34 \pm 23$ & $28 \pm 13$ & $41 \pm 10$ & - \\
\hline Mg & $69 \pm 26$ & $72 \pm 19$ & $71 \pm 23$ & $76 \pm 56$ & - \\
\hline Cl & $188 \pm 141$ & $58 \pm 36$ & $90 \pm 39$ & $122 \pm 39$ & - \\
\hline $\mathbf{K}, \%$ & $0.15 \pm 0.07$ & $0.19 \pm 0.06$ & $0.19 \pm 0.02$ & $0.12 \pm 0.04$ & - \\
\hline $\mathrm{Ca}$ & $49 \pm 18$ & $69 \pm 16$ & $38 \pm 7$ & $80 \pm 6.5$ & - \\
\hline Sc & $0.0006 \pm 0.0005$ & $0.003 \pm 0.003$ & $0.0002 \pm 0.0001$ & $0.0003 \pm 0.0001$ & - \\
\hline $\mathrm{Cr}$ & $0.044 \pm 0.032$ & $0.067 \pm 0.65$ & $0.024 \pm 0.004$ & $0.028 \pm 0.01$ & 0.2 \\
\hline Mn & $0.85 \pm 0.4$ & $0.65 \pm 0.3$ & $0.9 \pm 0.6$ & $0.53 \pm 0.12$ & - \\
\hline $\mathrm{Fe}$ & $5.5 \pm 2.6$ & $6.6 \pm 6.5$ & $2.6 \pm 1.9$ & $4.5 \pm 0.7$ & - \\
\hline Co & $0.03 \pm 0.03$ & $0.017 \pm 0.013$ & $0.013 \pm 0.003$ & $0.008 \pm 0.002$ & - \\
\hline $\mathbf{N i}$ & $0.13 \pm 0.07$ & $0.04 \pm 0.01$ & $0.05 \pm 0.01$ & $0.05 \pm 0.01$ & - \\
\hline $\mathrm{Cu}$ & $1.5 \pm 0.8$ & $1.0 \pm 0.7$ & $2.3 \pm 0.4$ & $0.65 \pm 0.3$ & - \\
\hline Zn & $7.4 \pm 6.9$ & $8.4 \pm 6.9$ & $8.5 \pm 4.2$ & $4.77 \pm 0.85$ & - \\
\hline As & $0.007 \pm 0.003$ & $0.029 \pm 0.022$ & $0.006 \pm 0.003$ & $<0.003$ & 0.5 \\
\hline Se & $1.08 \pm 0.75$ & $0.21 \pm 0.2$ & $0.04 \pm 0.02$ & $0.02 \pm 0.01$ & 0.5 \\
\hline $\mathrm{Br}$ & $1.6 \pm 1.3$ & $0.41 \pm 0.4$ & $0.44 \pm 0.05$ & $0.05 \pm 0.02$ & - \\
\hline $\mathbf{R b}$ & $20.3 \pm 18$ & $21.3 \pm 20.7$ & $21.5 \pm 21.3$ & $16.2 \pm 2.1$ & - \\
\hline Mo & $0.03 \pm 0.01$ & $<0.01$ & $0.02 \pm 0.01$ & $<0.01$ & - \\
\hline Cd & $0.13 \pm 0.11$ & $0.06 \pm 0.05$ & $0.04 \pm 0.03$ & $0.06 \pm 0.02$ & 0.03 \\
\hline Ag & $0.09 \pm 0.08$ & $0.26 \pm 0.23$ & $0.03 \pm 0.01$ & $<0.01$ & - \\
\hline Sb & $0.06 \pm 0.05$ & $0.004 \pm 0.002$ & $0.003 \pm 0.001$ & $0.008 \pm 0.004$ & 0.3 \\
\hline I & $0.007 \pm 0.007$ & $0.002 \pm 0.001$ & $0.004 \pm 0.002$ & $0.003 \pm 0.002$ & - \\
\hline Cs & $0.19 \pm 0.12$ & $0.11 \pm 0.09$ & $0.07 \pm 0.06$ & $0.21 \pm 0.12$ & - \\
\hline $\mathbf{L a}$ & $0.004 \pm 0.003$ & $0.009 \pm 0.006$ & $<0.003$ & $<0.003$ & - \\
\hline $\mathbf{W}$ & $<0.01$ & $<0.01$ & $<0.01$ & $<0.01$ & - \\
\hline $\mathbf{A u}$ & $0.0003 \pm 0.0003$ & $0.0003 \pm 0.0003$ & $0.0002 \pm 0.0001$ & $0.0001 \pm 0.0001$ & - \\
\hline $\mathbf{H g}$ & $0.06 \pm 0.05$ & $0.039 \pm 0.036$ & $0.01 \pm 0.004$ & $0.011 \pm 0.003$ & 0.05 \\
\hline Th & $0.001 \pm 0.0005$ & $0.003 \pm 0.002$ & $0.001 \pm 0.001$ & $<0.001$ & - \\
\hline $\mathbf{P b}$ & $0.04 \pm 0.02$ & $0.029 \pm 0.01$ & $0.03 \pm 0.01$ & $<0.02$ & 0.5 \\
\hline
\end{tabular}

trace elements concentration we suggest to use a concept of concentration factor $\mathrm{K}_{\mathrm{c}}$. This factor is widely used in ecology and geochemistry and provides a numerical estimation of the element accumulation in a sample relative to the "background" object. Numerically, it is the ratio of the element concentration in the test object to the concentration of the same element in the similar "background" object.
$\mathrm{K}_{\mathrm{c}}=\mathrm{C}_{\mathrm{i}} / \mathrm{C}_{\mathrm{ib}}$, where

$\mathrm{C}_{\mathrm{i}}$ is the concentration of the $\mathrm{i}$-th element in the test object;

$\mathrm{C}_{\mathrm{ib}}$ is the concentration of the $\mathrm{i}$-th element in the "background" (or conditional background) object.

Since it appeared to be complicated to find a "background" object for each fungus in our case, we used the conditional "background" object for each ecotrophic 
Table 2. The concentration of trace elements in saprotrophic fungi, mcg/g (with humidity).

\begin{tabular}{|c|c|c|c|c|}
\hline Element & $\begin{array}{c}\text { Russula vesca } \\
\quad \mathrm{n}=15\end{array}$ & $\begin{array}{l}\text { Lactarius torminosus } \\
\qquad \mathrm{n}=6\end{array}$ & $\begin{array}{l}\text { Paxillus involutus } \\
\mathrm{n}=\mathbf{2 2}\end{array}$ & MPC \\
\hline $\mathbf{N a}$ & $73 \pm 39$ & $19 \pm 5$ & $28 \pm 19$ & - \\
\hline Mg & $1734 \pm 298$ & $103 \pm 35$ & $121 \pm 57$ & - \\
\hline $\mathbf{C l}$ & $1878 \pm 523$ & $39 \pm 20$ & $25 \pm 23$ & - \\
\hline $\mathbf{K}, \%$ & $0.41 \pm 0.12$ & $0.16 \pm 0.07$ & $0.33 \pm 0.15$ & - \\
\hline $\mathbf{C a}$ & $46 \pm 14$ & $54 \pm 28$ & $54 \pm 28$ & - \\
\hline Sc & $0.003 \pm 0.002$ & $0.002 \pm 0.001$ & $0.002 \pm 0.001$ & - \\
\hline $\mathrm{Cr}$ & $0.10 \pm 0.07$ & $0.06 \pm 0.05$ & $0.05 \pm 0.04$ & 0.2 \\
\hline Mn & $1.7 \pm 1.1$ & $1.26 \pm 0.5$ & $1.5 \pm 1.5$ & - \\
\hline $\mathrm{Fe}$ & $9.9 \pm 4.3$ & $8.37 \pm 3.2$ & $12.9 \pm 4.3$ & - \\
\hline Co & $0.05 \pm 0.04$ & $0.023 \pm 0.012$ & $0.032 \pm 0.023$ & - \\
\hline $\mathbf{N i}$ & $0.19 \pm 0.13$ & $0.14 \pm 0.05$ & $0.10 \pm 0.05$ & - \\
\hline $\mathbf{C u}$ & $2.2 \pm 0.3$ & $1.13 \pm 0.31$ & $3.2 \pm 0.95$ & - \\
\hline $\mathbf{Z n}$ & $7.9 \pm 1.1$ & $5.57 \pm 0.8$ & $10 \pm 4.6$ & - \\
\hline As & $0.01 \pm 0.01$ & $0.039 \pm 0.02$ & $0.041 \pm 0.03$ & 0.5 \\
\hline Se & $0.02 \pm 0.01$ & $0.05 \pm 0.04$ & $0.07 \pm 0.02$ & 0.5 \\
\hline $\mathrm{Br}$ & $0.19 \pm 0.08$ & $0.07 \pm 0.04$ & $0.37 \pm 0.35$ & - \\
\hline $\mathbf{R b}$ & $2.16 \pm 0.45$ & $47 \pm 36$ & $15 \pm 14$ & - \\
\hline Mo & $0.007 \pm 0.003$ & $<0.01$ & $0.024 \pm 0.02$ & - \\
\hline Cd & $0.023 \pm 0.01$ & $0.02 \pm 0.01$ & $0.02 \pm 0.01$ & 0.03 \\
\hline Ag & $0.1 \pm 0.06$ & $0.02 \pm 0.007$ & $0.054 \pm 0.03$ & - \\
\hline Sb & $0.01 \pm 0.093$ & $0.007 \pm 0.004$ & $0.003 \pm 0.002$ & 0.3 \\
\hline $\mathbf{I}$ & $0.073 \pm 0.006$ & $0.005 \pm 0.004$ & $0.006 \pm 0.003$ & - \\
\hline Cs & $0.01 \pm 0.004$ & $0.97 \pm 0.78$ & $0.22 \pm 0.12$ & - \\
\hline $\mathbf{L a}$ & $0.013 \pm 0.006$ & $0.005 \pm 0.002$ & $0.025 \pm 0.013$ & - \\
\hline $\mathbf{W}$ & $0.031 \pm 0.03$ & $<0.01$ & $<0.01$ & - \\
\hline $\mathbf{A u}$ & $0.0001 \pm 0.0001$ & $0.0001 \pm 0.0001$ & $0.0019 \pm 0.0013$ & - \\
\hline Hg & $0.005 \pm 0.002$ & $0.008 \pm 0.005$ & $0.006 \pm 0.003$ & 0.05 \\
\hline Th & $0.002 \pm 0.001$ & $0.001 \pm 0.001$ & $0.006 \pm 0.005$ & - \\
\hline $\mathbf{P b}$ & $0.05 \pm 0.01$ & $0.09 \pm 0.03$ & $0.086 \pm 0.03$ & 0.5 \\
\hline Element & $\begin{array}{l}\text { Cantharellus cibarius } \\
\qquad \mathbf{n}=17\end{array}$ & $\begin{array}{l}\text { Agaricus campestris } \\
\qquad \mathbf{n}=\mathbf{2 1}\end{array}$ & $\begin{array}{l}\text { Lactarius deterrimus } \\
\qquad \mathrm{n}=\mathbf{5}\end{array}$ & MPC \\
\hline $\mathbf{N a}$ & $52 \pm 34$ & $63 \pm 61$ & $25 \pm 2.5$ & - \\
\hline Mg & $1431 \pm 283$ & $158 \pm 70$ & $111 \pm 17$ & - \\
\hline $\mathbf{C l}$ & $1133 \pm 386$ & $300 \pm 197$ & $52 \pm 4.3$ & - \\
\hline $\mathbf{K}, \%$ & $0.22 \pm 0.05$ & $0.37 \pm 0.07$ & $0.19 \pm 0.02$ & - \\
\hline $\mathrm{Ca}$ & $45 \pm 7$ & $50 \pm 21$ & $51 \pm 5.0$ & - \\
\hline Sc & $0.001 \pm 0.001$ & $0.0004 \pm 0.0003$ & $0.003 \pm 0.001$ & - \\
\hline $\mathrm{Cr}$ & $0.05 \pm 0.02$ & $0.05 \pm 0.03$ & $0.06 \pm 0.01$ & 0.2 \\
\hline Mn & $3.3 \pm 1.3$ & $0.67 \pm 0.09$ & $1.1 \pm 0.2$ & - \\
\hline $\mathrm{Fe}$ & $11.6 \pm 7.9$ & $5.6 \pm 2.9$ & $9.69 \pm 1.2$ & - \\
\hline Co & $0.025 \pm 0.01$ & $0.06 \pm 0.06$ & $0.01 \pm 0.007$ & - \\
\hline $\mathbf{N i}$ & $0.08 \pm 0.07$ & $0.08 \pm 0.04$ & $0.19 \pm 0.06$ & - \\
\hline $\mathrm{Cu}$ & $3.73 \pm 1.4$ & $14.1 \pm 8.1$ & $1.4 \pm 0.31$ & - \\
\hline $\mathbf{Z n}$ & $6.84 \pm 2.9$ & $7.3 \pm 2.1$ & $13 \pm 0.6$ & - \\
\hline As & $0.015 \pm 0.01$ & $0.13 \pm 0.09$ & $0.05 \pm 0.01$ & 0.5 \\
\hline
\end{tabular}


Continued

\begin{tabular}{ccccc}
\hline Se & $0.05 \pm 0.05$ & $0.65 \pm 0.55$ & $0.11 \pm 0.05$ & $0.12 \pm 0.02$ \\
Br & $0.14 \pm 0.08$ & $0.36 \pm 0.33$ & $5.8 \pm 1.0$ & - \\
Rb & $52 \pm 8.1$ & $0.43 \pm 0.31$ & $<0.01$ & - \\
Mo & $0.03 \pm 0.02$ & $0.011 \pm 0.005$ & $0.03 \pm 0.007$ & - \\
Cd & $0.02 \pm 0.01$ & $1.8 \pm 1.4$ & $<0.01$ & $\mathbf{0 . 0 3}$ \\
Ag & $0.012 \pm 0.007$ & $1.23 \pm 0.81$ & $0.003 \pm 0.007$ & - \\
Sb & $0.007 \pm 0.005$ & $0.007 \pm 0.006$ & $0.006 \pm 0.005$ & - \\
I & $0.095 \pm 0.052$ & $0.011 \pm 0.009$ & $<0.01$ & - \\
Cs & $0.65 \pm 0.21$ & $0.003 \pm 0.002$ & $0.01 \pm 0.004$ & - \\
La & $0.009 \pm 0.007$ & $0.009 \pm 0.008$ & $<0.01$ & - \\
W & $<0.01$ & $<0.01$ & $0.0001 \pm 0.0001$ & - \\
Au & $0.0002 \pm 0.0001$ & $0.19 \pm 0.15$ & $0.008 \pm 0.001$ & $\mathbf{0 . 0 5}$ \\
Hg & $0.008 \pm 0.006$ & $0.61 \pm 0.55$ & $0.003 \pm 0.001$ & - \\
Th & $0.002 \pm 0.001$ & $0.006 \pm 0.002$ & $0.053 \pm 0.01$ & $\mathbf{0 . 5}$ \\
Pb & $0.17 \pm 0.05$ & $0.11 \pm 0.05$ & & - \\
\hline
\end{tabular}

Table 3. The concentration of trace elements in hemibiotrophs, mcg/g (with humidity).

\begin{tabular}{|c|c|c|c|}
\hline Element & $\begin{array}{l}\text { Armillariella mellea } \\
\qquad \mathrm{n}=13\end{array}$ & $\begin{array}{l}\text { Pleurotus ostreatus } \\
\qquad \mathbf{n}=\mathbf{2 1}\end{array}$ & MPC \\
\hline $\mathbf{N a}$ & $16 \pm 5.5$ & $9.0 \pm 1.1$ & - \\
\hline Mg & $127 \pm 25$ & $133 \pm 48$ & - \\
\hline $\mathbf{C l}$ & $56 \pm 48$ & $35 \pm 0.09$ & - \\
\hline $\mathbf{K}, \%$ & $0.31 \pm 0.13$ & $0.48 \pm 0.09$ & - \\
\hline $\mathbf{C a}$ & $45 \pm 16$ & $99 \pm 32$ & - \\
\hline Sc & $0.0003 \pm 0.0002$ & $0.0002 \pm 0.0001$ & - \\
\hline $\mathrm{Cr}$ & $0.03 \pm 0.01$ & $0.019 \pm 0.01$ & 0.2 \\
\hline Mn & $1.53 \pm 0.2$ & $1.03 \pm 0.29$ & - \\
\hline $\mathrm{Fe}$ & $10.3 \pm 4.9$ & $8.86 \pm 0.9$ & - \\
\hline Co & $0.005 \pm 0.002$ & $0.01 \pm 0.005$ & - \\
\hline $\mathbf{N i}$ & $0.09 \pm 0.02$ & $0.035 \pm 0.02$ & - \\
\hline $\mathrm{Cu}$ & $2.1 \pm 0.4$ & $1.03 \pm 0.25$ & - \\
\hline $\mathbf{Z n}$ & $7.9 \pm 1.7$ & $6.1 \pm 0.8$ & - \\
\hline As & $<0.005$ & $0.01 \pm 0.003$ & 0.5 \\
\hline Se & $0.014 \pm 0.01$ & $0.06 \pm 0.04$ & 0.5 \\
\hline $\mathrm{Br}$ & $0.042 \pm 0.02$ & $0.05 \pm 0.02$ & - \\
\hline $\mathbf{R b}$ & $2.84 \pm 0.9$ & $1.09 \pm 0.36$ & - \\
\hline Mo & $0.014 \pm 0.005$ & $<0.01$ & - \\
\hline Cd & $0.42 \pm 0.15$ & $0.25 \pm 0.11$ & 0.03 \\
\hline Ag & $0.04 \pm 0.02$ & $0.031 \pm 0.01$ & - \\
\hline Sb & $0.003 \pm 0.001$ & $0.001 \pm 0.001$ & 0.3 \\
\hline I & $0.018 \pm 0.015$ & $0.005 \pm 0.003$ & - \\
\hline Cs & $0.042 \pm 0.019$ & $0.033 \pm 0.007$ & - \\
\hline La & $0.004 \pm 0.003$ & $0.013 \pm 0.01$ & - \\
\hline $\mathbf{W}$ & $0.013 \pm 0.007$ & $<0.01$ & - \\
\hline Au & $0.0002 \pm 0.0001$ & $0.0001 \pm 0.0001$ & - \\
\hline $\mathrm{Hg}$ & $0.003 \pm 0.002$ & $0.019 \pm 0.008$ & 0.05 \\
\hline Th & $0.002 \pm 0.002$ & $0.0008 \pm 0.0003$ & - \\
\hline $\mathbf{P b}$ & $0.08 \pm 0.02$ & $<0.05$ & 0.5 \\
\hline
\end{tabular}


group of fungi. For the symbiotrophs we chose Boletus edulis sampled in Iceland, where the human impact (except for global precipitations) is practically absent. For the saprotrophs we chose Agaricus bisporus grown in vitro and for the hemibiotrophs it was Pleurotus ostreatus cultivated in vitro as well.

Table 4 shows the average values of $\mathrm{K}_{\mathrm{c}}$ calculated for saprotrophs, symbiotrophs and hemibiotrophs on the basis of the data from Tables 1, 2 and 3 . These results show that mushrooms accumulate different chemical elements in addition to the above-mentioned $\mathrm{Se}, \mathrm{Cd}$ and $\mathrm{Hg}$. Symbiotrophs largely accumulate $\mathrm{Sc}, \mathrm{Cu}, \mathrm{Br}, \mathrm{Rb}, \mathrm{Cs}$ and Ag. Saprotrophs accumulate $\mathrm{Sc}, \mathrm{Co}, \mathrm{Ag}$ and $\mathrm{Au}$ and hemibiotrophs on the contrary accumulate almost nothing. The data presented in the Table 4 show that saprotrophs accumulate trace elements in the most intensive way (the arithmetic mean of the concentration factor is 167). Hemibiotrophs have the lowest concentration of the trace elements (the average $\mathrm{K}_{\mathrm{c}}=2.4$ ) which is probably due to the weak absorption of metals in the roots of the host plants. Mycorrhizal fungi occupy an intermediate position according to the accumulation degree of the trace elements (the average $\mathrm{K}_{\mathrm{c}}=7.7$ ). It is known that the hyphae of the symbiotrophs grow on the roots of various plant species and they reflect the elements availability in different soil horizons. It is probably the reason for the different accumulation of the elements by the symbiotrophs and the saprotrophs.

In order to assess the impact of the environment on the association of the accumulated trace elements and the degree of their concentration, we have sampled mycothalluses of the same fungi in different ecological and geochemical conditions. Samples of Agaricus campestris were taken in the conditions of the intensive anthropogenic impact and the samples of Boletus edulis in conditions close to the "background." The sampling of Agaricus campestris was held in the large city (Moscow) in 5 areas with different levels of anthropogenic pressure [8, 10]. The samples were taken:

1) in the north of Moscow near the district North Medvedkovo with the lowest level of industrial pollution (zone № 1);

2) in the center of Moscow on the street Shabolovskaya with a high level of industrial pollution (zone № 2);

3 ) in the south-east of Moscow in the district Pechatniki with the highest level of industrial pollution (zone № $3)$;

4) $10 \mathrm{~km}$ away from the Moscow Automobile Ring Road in the forest belt of the Simferopol highway (zone № 4);

5) in the south of the Moscow region, $160 \mathrm{~km}$ away from Moscow in an area with mainly agricultural activity with a low level of industrial pollution (zone № 5).

The data listed in the Table 5 illustrate well that the
Table 4. The concentration factors for different groups of fungi, relative units.

\begin{tabular}{|c|c|c|c|}
\hline \multirow{2}{*}{ Element } & \multicolumn{3}{|c|}{$\mathbf{K}_{\mathrm{c}}$} \\
\hline & Saprotrophs & Symbiotrophs & Hemibiotrophs \\
\hline $\mathbf{N a}$ & 3.7 & 3.1 & 1.7 \\
\hline Mg & 1.9 & 3.8 & 1 \\
\hline Cl & 3.4 & 4.8 & 1.6 \\
\hline $\mathbf{K}$ & 0.9 & 2.5 & 1.3 \\
\hline $\mathrm{Ca}$ & 1.8 & 1.7 & 1.2 \\
\hline Sc & 11.5 & 8.5 & 4 \\
\hline $\mathrm{Cr}$ & 3 & 2.5 & 2 \\
\hline Mn & 3.8 & 2.3 & 2.8 \\
\hline $\mathbf{F e}$ & 2.4 & 2.6 & 1.2 \\
\hline Co & 150 & 3.3 & 0.9 \\
\hline $\mathbf{N i}$ & 8 & 2.2 & 3 \\
\hline $\mathrm{Cu}$ & 11.5 & 5.4 & 3 \\
\hline $\mathbf{Z n}$ & 2.4 & 2.4 & 1.6 \\
\hline As & 14 & 2.7 & 1.4 \\
\hline Se & 7 & 16.0 & 1.6 \\
\hline $\mathrm{Br}$ & 3.5 & 31.0 & 1 \\
\hline $\mathbf{R b}$ & 0.6 & 12.0 & 2.4 \\
\hline Mo & 1.0 & 2.5 & 1.9 \\
\hline Cd & 340.0 & 41.4 & 2.5 \\
\hline Ag & 3300.0 & 13.5 & 1.4 \\
\hline Sb & 5.5 & 4.0 & 2.1 \\
\hline $\mathbf{I}$ & 5.7 & 4.0 & 9 \\
\hline Cs & 1.5 & 35.0 & 6.1 \\
\hline La & 2.5 & 1.0 & 7 \\
\hline $\mathbf{W}$ & 4.0 & 1.0 & 2.3 \\
\hline Au & 810.0 & 1.5 & 1.5 \\
\hline Hg & 128.0 & 10.0 & 0.6 \\
\hline Th & 3.0 & 1.0 & 3 \\
\hline $\mathbf{P b}$ & 3.8 & 1.0 & 1.7 \\
\hline
\end{tabular}

concentrations of the trace elements in the mycothalluses of fungi depend on the environmental and geochemical conditions of the selected area. It is shown that the changes in the anthropogenic impact on the environment provoke insignificant changes in the association of accumulated trace elements but at the same time it causes wide alterations in the concentration levels. Champignons growing in the north of Moscow contain high concentrations of As, Se, Cd and $\mathrm{Ag}\left(\mathrm{K}_{\mathrm{c}}=7.4\right.$ - 104). Mushrooms picked in the center of Moscow are characterized by high concentrations of $\mathrm{Cu}, \mathrm{Cd}\left(\mathrm{K}_{\mathrm{c}}=3-22\right)$, $\mathrm{Ag}, \mathrm{Hg}$ and $\mathrm{Au}\left(\mathrm{K}_{\mathrm{c}}=114-3300\right)$. For champignons 
Table 5. Concentration factors of trace elements in champignons (Agaricus campestris) depending on the place of growth, relative units.

\begin{tabular}{|c|c|c|c|c|c|}
\hline Sampling location element & 1 & 2 & 3 & 4 & 5 \\
\hline $\mathbf{N a}$ & 0.6 & 3.7 & 0.7 & 0.3 & 0.3 \\
\hline $\mathbf{M g}$ & 0.7 & 0.6 & 1.9 & 0.9 & 1.0 \\
\hline $\mathbf{C l}$ & 1.9 & 2.1 & 3.4 & 2.6 & 0.4 \\
\hline $\mathbf{K}$ & 0.6 & 0.7 & 0.9 & 0.9 & 0.9 \\
\hline $\mathrm{Ca}$ & 1.8 & 1.1 & 1.3 & 0.8 & 0.7 \\
\hline Sc & 0.5 & 0.5 & 1.0 & 11.5 & 0.5 \\
\hline $\mathrm{Cr}$ & 1.5 & 3.0 & 2.5 & 2.5 & 1.5 \\
\hline Mn & 1.0 & 0.8 & 2.2 & 3.8 & 2.0 \\
\hline $\mathrm{Fe}$ & 0.9 & 0.9 & 1.2 & 2.4 & 1.7 \\
\hline Co & 2.5 & 2.5 & 12.5 & 150.0 & 2.5 \\
\hline $\mathbf{N i}$ & 1.0 & 1.0 & 3.0 & 8.0 & 1.7 \\
\hline $\mathrm{Cu}$ & 2.2 & 11.5 & 4.4 & 10.5 & 2.4 \\
\hline $\mathrm{Zn}$ & 1.4 & 2.0 & 1.2 & 2.4 & 1.2 \\
\hline As & 14.0 & 2.5 & 8.5 & 8.0 & 2.0 \\
\hline Se & 7.4 & 1.1 & 6.8 & 1.1 & 4.2 \\
\hline $\mathrm{Br}$ & 0.5 & 1.1 & 1.6 & 1.6 & 3.7 \\
\hline $\mathbf{R b}$ & 0.1 & 0.1 & 0.6 & 1.3 & 0.4 \\
\hline Mo & 1.0 & 1.1 & 1.0 & 1.3 & 1.3 \\
\hline $\mathrm{Cd}$ & 104.4 & 22.2 & 18.9 & 377.8 & 20.0 \\
\hline Ag & 40.0 & 3300.0 & 1900.0 & 300.0 & 70.0 \\
\hline $\mathbf{S b}$ & 1.0 & 1.0 & 3.5 & 5.5 & 0.5 \\
\hline I & 1.0 & 0.7 & 2.8 & 2.3 & 5.7 \\
\hline Cs & 1.0 & 0.5 & 1.5 & 0.5 & 1.5 \\
\hline $\mathbf{L a}$ & 2.5 & 2.5 & 2.5 & 2.5 & 2.5 \\
\hline $\mathbf{W}$ & 1.0 & 1.0 & 1.0 & 5.0 & 1.0 \\
\hline $\mathbf{A u}$ & 1.0 & 170.0 & 810.0 & 28.0 & 10.0 \\
\hline $\mathrm{Hg}$ & 3.0 & 114.0 & 128.0 & 87.0 & 8.0 \\
\hline Th & 1.0 & 1.0 & 1.0 & 3.0 & 1.0 \\
\hline $\mathbf{P b}$ & 2.2 & 4.0 & 1.1 & 4.2 & 1.1 \\
\hline
\end{tabular}

sampled in the south-east of Moscow the high concentrations of $\mathrm{As}, \mathrm{Se}, \mathrm{Cd}, \mathrm{Ag}, \mathrm{Au}$ and $\mathrm{Hg}$ are typical. The champignons collected in the forest belt of the Simferopol highway have high concentrations of $\mathrm{Sc}, \mathrm{Co}, \mathrm{Ni}, \mathrm{Cu}$, $\mathrm{As}, \mathrm{Cd}, \mathrm{Au}$ and $\mathrm{Hg}$. In the agricultural area in the south of Moscow Oblast high concentrations of $\mathrm{Cd}, \mathrm{Ag}, \mathrm{Au}$ and $\mathrm{Hg}$ were revealed despite the low level of industrial pollution. In consideration of the above, we should note that the same fungi species accumulate similar associations of the trace elements in almost the same climatic conditions, and the most accumulated trace elements are $\mathrm{Co}, \mathrm{Cd}, \mathrm{Ag}, \mathrm{Au}$ and $\mathrm{Hg}$.

Table 5 shows the variation of the trace element composition of fungi typical to the region with a very intense anthropogenic pressure on the environment. Table 6 shows the distribution of the trace elements in the 
Table 6. Concentration factors of trace elements in cepes (Boletus edulis) depending on the place of growth, relative units.

\begin{tabular}{|c|c|c|c|c|}
\hline $\begin{array}{c}\text { Sampling location } \\
\text { element }\end{array}$ & 1 & 2 & 3 & 4 \\
\hline $\mathbf{N a}$ & 1.3 & 0.8 & 0.4 & 0.5 \\
\hline Mg & 0.8 & 1.0 & 0.7 & 0.3 \\
\hline Cl & 1.8 & 4.8 & 3.7 & 2.4 \\
\hline $\mathbf{K}$ & 0.7 & 0.6 & 1.2 & 0.5 \\
\hline $\mathrm{Ca}$ & 1.2 & 1.0 & 0.8 & 0.7 \\
\hline Sc & 0.2 & 0.2 & 0.1 & 0.3 \\
\hline $\mathrm{Cr}$ & 1.3 & 1.0 & 0.7 & 1.7 \\
\hline Mn & 1.4 & 2.3 & 1.3 & 1.4 \\
\hline $\mathrm{Fe}$ & 0.5 & 0.4 & 0.4 & 0.6 \\
\hline Co & 2.1 & 3.3 & 1.0 & 2.8 \\
\hline $\mathbf{N i}$ & 2.2 & 2.2 & 1.3 & 1.3 \\
\hline $\mathbf{C u}$ & 1.9 & 1.8 & 3.5 & 0.7 \\
\hline $\mathrm{Zn}$ & 1.0 & 0.4 & 1.1 & 0.5 \\
\hline As & 2.7 & 1.7 & 2.3 & 1.7 \\
\hline Se & 16.0 & 3.0 & 1.0 & 14.0 \\
\hline $\mathrm{Br}$ & 11.0 & 31.0 & 30.0 & 27.0 \\
\hline $\mathbf{R b}$ & 12.0 & 3.7 & 2.9 & 1.7 \\
\hline Мo & 0.6 & 0.2 & 0.6 & 0.4 \\
\hline $\mathrm{Cd}$ & 13.5 & 6.5 & 2.5 & 1.5 \\
\hline Ag & 41.4 & 22.9 & 13.0 & 3.3 \\
\hline Sb & 4.0 & 2.0 & 2.0 & 1.0 \\
\hline I & 0.5 & 1.3 & 2.0 & 1.3 \\
\hline Cs & 35.0 & 11.0 & 14.0 & 4.0 \\
\hline La & 1.0 & 1.0 & 1.0 & 1.0 \\
\hline $\mathbf{W}$ & 1.0 & 1.0 & 1.0 & 1.0 \\
\hline $\mathbf{A u}$ & 1.0 & 1.0 & 1.0 & 1.5 \\
\hline Hg & 10.0 & 10.0 & 0.7 & 7.1 \\
\hline Th & 1.0 & 1.0 & 1.0 & 1.0 \\
\hline $\mathbf{P b}$ & 1.0 & 1.0 & 1.0 & 1.0 \\
\hline
\end{tabular}

cepes sampled in the areas with the low anthropogenic pressure.

Sampling of the cepes mycothalluses was held:

1 ) in the east of the Tver Oblast (zone № 1);

2 ) in the south of the Moscow Oblast (zone № 2);

3 ) in the Kandalaksha Nature reserve in the Arkhangelsk Oblast (zone № 3);

4 ) in the central part of The Kostomuksha Nature Reserve (zone № 4).

The analysis of the data presented in the Table 6 shows that no high concentrations of $\mathrm{Cr}, \mathrm{As}, \mathrm{Sb}$ and $\mathrm{Pb}$ were observed in the cepes mycothalluses in these regions. In the south of the Moscow Oblast and in The Kostomuksha Nature Reserve an increase in the concen- tration of Se was revealed. Almost everywhere, there are high concentrations of $\mathrm{Br}, \mathrm{Cd}, \mathrm{Ag}, \mathrm{Cs}$ and $\mathrm{Hg}$. In general, the difference in the concentrations of most trace elements in cepes collected in the Moscow Oblast, the Kandalaksha Nature reserve and The Kostomuksha Nature Reserve are insignificant-1.5 - 2.5-fold. However, certain trace elements show 10 - up to 40 -fold difference. The data presented in the Tables $\mathbf{5}$ and $\mathbf{6}$ show that both fungi species accumulate the same association of the trace elements - $\mathrm{Co}, \mathrm{Cu}, \mathrm{Se}, \mathrm{Cd}, \mathrm{Ag}, \mathrm{Au}$ and $\mathrm{Hg}$. Boletus edulis concentrates $\mathrm{Br}$ and $\mathrm{Cs}$ as well. Thus, it is clear that the association of the concentrated elements remains fairly constant and is represented by 7 - 9 trace elements, and only the degree of concentration changes. For example, the concentration factor for $\mathrm{Ag}$ decreases from $\mathrm{K}_{\mathrm{c}}=$ 3300 for Agaricus campestris in the area of intensive anthropogenic impact to $\mathrm{K}_{\mathrm{c}}=40$ for Boletus edulis in a "background" zone. Among the accumulated trace elements there are toxic elements (As, $\mathrm{Se}, \mathrm{Cd}$ and $\mathrm{Hg}$ ), essential elements $(\mathrm{Co}$ and $\mathrm{Cu}$ ), and precious metals, but no $\mathrm{Mn}, \mathrm{Fe}, \mathrm{Zn}$, which are mentioned in the literature as necessary for the vital functions of mycelium $[4,12]$. Moreover, toxic elements and precious metals are the most accumulated in fungi mycothalluses, what cannot be explained from the point of view of the biochemical processes in the mycelium.

It should be noted that the specific character of the osmotrophic nutrition of fungi may be the reason for higher concentrations of certain elements in the mycelium that exceed the concentrations of mobile forms of these elements in the substratum. In order to confirm or refute this assumption we have selected mycorrhizal fungi, litter saprophytes and hemibiotrophs in various districts of the Moscow Oblast. Together with fungi the soil samples were selected up to depth of $0.5 \mathrm{~m}$. In the case of parasitic fungi the wood was sampled as well. Table 7 presents the concentrations of $\mathrm{Ni}, \mathrm{Cu}, \mathrm{Zn}, \mathrm{Cd}$ and $\mathrm{Pb}$ in the mycothalluses of Leccinum aurantiacum, Boletus edulis, Agaricus campestris, Lactarius torminosus, Pleurotus ostreatus and Polyporus squamosus. In addition, there are data on the concentrations of mobile forms of the compounds of these metals in the litter and soil horizons lying below (ammonium-acetate extract $\mathrm{pH}$ 4.8).

The data presented in the Table 7 show that the concentrations of $\mathrm{Cu}, \mathrm{Zn}$ and $\mathrm{Cd}$ in the mycothalluses of fungi are $1.5-10$ times higher than the concentrations of their mobile forms in the soil. For $\mathrm{Ni}$ and $\mathrm{Pb}$ an invert correlation is typical: the concentrations of mobile forms of these elements in the soil are significantly higher than their concentrations in the fungi mycothalluses. The analysis of the obtained results shows that fungi accumulate elements for which concentrations of the mobile forms in substratum are lower than the concentrations of 
Table 7. The concentration of some trace elements in mushrooms and the distribution of their mobile forms in the substratum, mg/kg (with humidity).

\begin{tabular}{|c|c|c|c|c|c|c|}
\hline Element & $\mathbf{N i}$ & $\mathrm{Cu}$ & $\mathbf{Z n}$ & Cd & $\mathbf{P b}$ & pH \\
\hline \multicolumn{7}{|c|}{ Symbiotrophs } \\
\hline Leccinum aurantiacum & 0.06 & 2.73 & 6.99 & 0.2 & 0.56 & - \\
\hline Litter $(0-3)$ & 0.55 & 0.2 & 6.54 & 0.26 & 21 & 4.60 \\
\hline$A_{0}-A_{1}(3-10)$ & 0.58 & 0.24 & 3.43 & 0.18 & 12.5 & 4.70 \\
\hline B $(10-40)$ & 0.63 & 0.22 & 2.33 & 0.13 & 7.2 & 5.32 \\
\hline Boletus edulis & 0.13 & 5.82 & 9.1 & 0.27 & 0.1 & - \\
\hline Litter $(0-3)$ & 4.54 & 6.8 & 9 & 0.35 & 1.8 & 4.70 \\
\hline$A_{0}-A_{1}(3-10)$ & 0.46 & 2.9 & 1.8 & 0.18 & 1.7 & 4.75 \\
\hline B $(10-40)$ & 0.13 & 1.6 & 0.5 & 0.02 & 1.1 & 5.10 \\
\hline \multicolumn{7}{|c|}{ Saprotrophs } \\
\hline Agaricus campestris & 0.21 & 12.1 & 11.3 & 3.3 & 0.05 & - \\
\hline Litter $(0$ - 3) & 0.3 & 0.91 & 5.4 & 1.72 & 0.23 & 4.30 \\
\hline$A_{0}-A_{1}(3-10)$ & 0.16 & 0.05 & 1.42 & 0.03 & 0.41 & 4.55 \\
\hline $\mathrm{B}(10-40)$ & 0.19 & 0.05 & 0.94 & 0.03 & 0.5 & 4.90 \\
\hline Lactarius torminosus & 0.07 & 1.12 & 6.01 & 0.04 & 0.03 & - \\
\hline Litter $(0-1)$ & 1.04 & 0.13 & 2.15 & 0.07 & 0.79 & 4.20 \\
\hline$A_{0}-A_{1}(1-10)$ & 1.06 & 0.15 & 0.87 & 0.07 & 0.67 & 4.50 \\
\hline B $(10-40)$ & 1.05 & 0.13 & 0.71 & 0.06 & 0.74 & 5.40 \\
\hline \multicolumn{7}{|c|}{ Hemibiotrophs } \\
\hline Pleurotus ostreatus & 0.035 & 1 & 6.1 & 0.26 & 0.02 & - \\
\hline Substratum, wood (gross) & 0.3 & 1.5 & 10 & 0.3 & 0.15 & - \\
\hline Polyporus squamosus & $<0.05$ & 2.09 & 4.1 & 0.05 & $<0.05$ & - \\
\hline Substratum, wood (gross) & 1.05 & 2.98 & 5.95 & 0.04 & 0.38 & - \\
\hline
\end{tabular}

these elements in the mycothallus. Apparently, it can be explained through the specific character of the osmotrophic nutrition of fungi. It is known that osmosis is always directed from a less concentrated solution to a more concentrated one. In our case, the more concentrated solution of $\mathrm{Cu}, \mathrm{Zn}$ and $\mathrm{Cd}$ is in the body of the mycelium, and the role of a semipermeable membrane is played by a cell wall of fungus hypha. Thus, the high concentration of a trace element in the mycelium is a necessary condition for the further accumulation of this element by the fungus. However, this assumption needs to be proved in further researches. Alignment of the trace element concentration in the mycelium and soil solution and especially its reduction relative to the concentration in the soil solution is a barrier to the further accumulation of this element, which is reflected in the data presented in Table 7.

\section{Conclusions}

Trace elements are most accumulated by the saprotrophs and least accumulated by the hemibiotrophs. Mycorrhizal fungi (symbiotrophs) have an intermediate degree of trace elements accumulation. Such elements as $\mathrm{Co}, \mathrm{Cu}$, $\mathrm{Se}, \mathrm{Br}, \mathrm{Ag}, \mathrm{Cd}, \mathrm{Cs}, \mathrm{Au}$ and $\mathrm{Hg}$ are most accumulated in fungi.

The concentration degree of heavy and toxic metals in mushrooms apparently depends on the partial pressure of the compounds of these trace elements, the presence and concentrations of the mobile forms of these trace elements in the soil solution. The greater the difference of trace element concentrations in the mycelium and its mobile forms in the substratum is, the more intense the element gets. At the same time, the concentration of the trace element in the mycelium should be higher than the 
concentration of its mobile forms in the substrate. When the opposite is observed, the accumulation of the trace element in the mycelium does not happen.

In order to evaluate the mechanism of the trace element accumulation by basidiomycetes in details, a further study of trace element composition of the soil solutions, mycelium, mycothalluses and spores is necessary.

\section{REFERENCES}

[1] A. R. Burn, B. Ravnik and L. Kosta, "Trace Element Concentrations in Fungi," Science of the Total Environment, Vol. 6, No. 1, 1976, pp. 65-78. http://dx.doi.org/10.1016/0048-9697(76)90007-3

[2] A. Kabata-Pendias and H. Pendias, "Trace Elements in Soils and Plants," CRC Press, Boca Raton, 2001.

[3] P. Kalac, "Chemical Composition and Nutritional Value of European Species of Wild Growing Mushrooms: A Review," Food Chemistry, Vol. 113, No. 1, 2009, pp. 916. http://dx.doi.org/10.1016/j.foodchem.2008.07.077

[4] R. Bagalii, "Biogeochemistry of the Geophytes," Geos, Moscow, 2005.

[5] M. N. Kataeva, "Concentrations of Different Chemical Elements in the Mycothalluses of Macromycetes in the Mountain Tundras of Polar Urals. Mycology and Phytopathology," Science, Vol. 44, No. 3, 2010, pp. 240-247.

[6] Z. Randa and J. Kucera, "Trace Elements in Higher Fungi (Mushrooms) Determined by Activation Analysis," Journal of Radioanalytical and Nuclear Chemistry, Vol. 259, No. 1, 2004, pp. 99-107.
http://dx.doi.org/10.1023/B:JRNC.0000015813.27926.32

[7] Z. Randa, L. Soukal and J. Mizera, "Possibilities of the Short-Term Thermal and Epithermal Neutron Activation for Analysis of Macromycetes (Mushrooms)," Journal of Radioanalytical and Nuclear Chemistry, Vol. 264, No. 1, 2005, pp. 67-76.

http://dx.doi.org/10.1007/s10967-005-0676-y

[8] A. V. Gorbunov, S. M. Lyapunov, O. I. Okina, M. V. Frontasyeva and S. S. Pavlov, "Nuclear and Related Analytical Techniques in Ecology: Impact of Geoecological on the Balance of Trace Elements in the Human Organism," Physics of Particles and Nuclei, Vol. 43, No. 6, 2012, pp. 783-824.

http://dx.doi.org/10.1134/S1063779612060044

[9] E. J. Wyse, S. Asemard and S. J. de Mora, "World-Wide Intercomparison Exercise for the Determination of Trace Elements and Methylmercury in Fish Homogenate IAEA407," IAEA Marine Environment Laboratory, 2003, p. 25.

[10] E. J. Wyse, S. Asemard and S. J. de Mora, "World-Wide Intercomparison Exercise for the Determination of Trace Elements and Methylmercury in Marine Sediment IAEA433," IAEA Marine Environment Laboratory, 2004, p. 23.

[11] "State Standards. Raw Materials and Foodstuffs," IPK, Standards Edition, 1998.

[12] A. A. Shirokikh and I. G. Shirokikh, "Heavy Metal Accumulation in Xylotroph Basidiomycetes in Urban Ecosystems. Mycology and Phytopatology," Science, Vol. 44, No. 4, 2010, pp. 359-366. 